\title{
Name, Memory, and Time in Racine's Trojan War Plays ${ }^{1}$
}

\author{
Nancy M. McElveen
}

\begin{abstract}
As naming gives heroic stature to the characters of Jean Racine's Andromache, it paradoxically reflects their demolition. Naming Andromache's ancestors focuses on the past, while naming absent family members in Iphigenia focuses on the future. Naming unifies the plays on the stage with their literary antecedents by creating a bond of familiarity between characters and audience. Absences made present by naming extend boundaries of time and space backward by coloring memories which determine the course of present actions and forward by hinting at future greatness.
\end{abstract}

In an essay on absence and memory in Thomas' Roman de Tristan, Brent A. Pitts describes the relationship between image and memory:

Images are pictures drawn from memory, but they may also represent a composite of discrete tableaux of the past. In this sense, an image is the composition of associations stored separately in memory. (795)

In all of the secular tragedies of Jean Racine, certain characters form, even in their absence, such a composite of tableaux against which the single tragic moment stands. Important from both a dramatic and a philosophical standpoint, a stock of characters absent from the stage yet present in the text of the play grows out of the seventeenth-century trend toward reviving the roles of Greek tragedy. As participants in that revival, playwrights occasionally found themselves obliged to revive on stage those characters who, in the

Names 42.1 (March 1994):27-37

ISSN:0027-7738

(C) 1994 by The American Name Society 
context of the play's logic or plot, had already died or disappeared (Prophète 9). The histories of those characters were so well-known that their very names at once called to mind a specific set of circumstances, certain definite relationships, and particular passions or crimes. The personages, living or dead, of whose presence the audience is deprived are relegated to the wings, but the memory of their existence affects the play's action as much as the presence of other personages on stage (Prophète 10).

In his study of Les Para-personnages dans les Tragédies de Racine, Jean Prophete proposes a typology of absent characters, in which he describes four groups of dramatic personages. The first group is made up of individual figures - kings, generals, queens, spouses, brothers, oracles; their role is to show the vanity of human wishes opposed to the hidden forces of fate (116). The second group consists of those whose ties, whether hereditary, moral, or religious, with the protagonists render them heirs to the mistakes and defects of their ancestors (116). Third are those who serve to make legitimate the actions of the protagonists; some, as repositories of traditions, beliefs, and values, represent public opinion (116). Closely allied to those beings is the fourth category, that of ideas, myths, legends, values, and beliefs which engender and orient acts and events, thus subordinating the wills of men to those forces which determine their fate and which they oppose in vain (117).

From Prophète's cast of 'para-personnages' come a group which might be called "stock" characters. They appear in each of the plays and form part of the background against which the drama is played. The list of "stock" characters includes the ancestors of the protagonists, crowds of soldiers and sailors, cities and locales which assume the nature of a character in the drama, and the pagan divinities which inhabit the world of Racine's tragedies. I would like to focus here on only one group, the ancestors of the protagonists in the Trojan War plays, Andromache and Iphigenia. It is convenient here to use the term "ancestors" as all-encompassing. In addition to ancestors, in the traditional sense, of Racinian protagonists, the term further expands to embrace the heroic contemporaries, companions, and enemies of the protagonists, especially in the plays of the Trojan War cycle. The tragedies are populated by absent 


\section{Names 42.1 (March 1994)}

ancestors in order to lend credibility to the setting, to remind protagonists of their proper roles, or to add dimension to the portraits of one or more of the protagonists.

Ancestors of dramatic personages may serve as the human framework within which events unfold (Prophète 83). Both Andromache and Iphigenia evoke the historical totality of an era. The subject of the two plays is the same, but one takes place just before the war's action begins, the other just after it ends. Andromache recounts events after the Iliad had ended; Iphigenia tells what happens as the Iliad begins.

As Andromache opens, the title character, widow of Hector of Troy, and her son Astyanax, are captives at the court of Pyrrhus, son of Achilles, who had killed Hector during the siege of Troy. Pyrrhus loves Andromache and wishes to marry her, but she consistently refuses his offers. Finally, Pyrrhus threatens to kill Astyanax if Andromache continues to refuse him. Orestes, son of Agamemnon, arrives at Pyrrhus' court to persuade Pyrrhus to give up Astyanax. However, Orestes is in love with Hermione, daughter of Menelaus and Helen of Troy; his interest lies in convincing her to return with him to Greece rather than in fulfilling his mission. Hermione, officially engaged to Pyrrhus, has lingered at court for nearly a year - the length of Andromache's captivity - waiting for Pyrrhus to fulfill his promises. Pyrrhus finally tells Orestes that he will hand over Astyanax and marry Hermione. But Andromache, faced with what will surely be her son's death, decides on an "innocent trick" (IV.1.1097): ${ }^{2}$ she will marry Pyrrhus but immediately afterward kill herself to avoid dishonoring Hector's memory. Hermione orders Orestes to murder Pyrrhus. The play ends with the assassination of Pyrrhus, the suicide of Hermione and the madness of Orestes. Only Andromache survives.

This first play in the cycle, first performed in 1667, is peopled by characters who look backward in time and evoke memories of the causes of the Trojan War and of the total destruction which resulted. Memories of the war's causes are evoked by mere mention of the names of Helen and Menelaus. Even as he reassures Andromache of his concern for her son, Pyrrhus recalls Helen's name: 
The whole of Greece has threatened me with war.

But, even should they cross the seas again

And with a vast armada claim your son,

Should it demand the blood for Helen shed,

I would, unwavering, hasten to his aid. (I.iv.282-286)

Most vivid of all are the images of the total destruction of Troy, destruction made visible in Act $I$ by the naming of such illustrious figures as Ulysses ("They tell me that, to save the boy from death,/ Andromache deceived Ulysses' guile" [I.i.73-74]) and Priam ("Ah! If the death of Hector's son were sworn,/Why did you wait until a year was by?/ On Priam's breast he should have been dispatched,/ Buried beneath the dying, under Troy" [I.ii.205-208]). Perhaps the starkest description of the destruction is contained in two lines which recall three of the city's inhabitants. In Act I, scene 2, Pyrrhus describes to Orestes the dividing of the spoils of war. Pyrrhus received as his lot Andromache and her son; to other victors went other lots:

Ulysses drew woe-laden Hecuba.

Cassandra took the road to Argos with

Your father. (I.i.189-191)

The Trojan War, itself an integral part of Andromache, is thus evoked by naming the ancestors of the protagonists. As such naming gives heroic stature to the characters of Andromache, it paradoxically reflects the demolition of the heroes. John C. Lapp remarks on the contrast between the characters of Racine's drama and their illustrious predecessors:

The constant presence, in the memories of the characters, of the events at Troy, provides a scale against which they are measured and found wanting. (17) 


\section{Names 42.1 (March 1994)}

P. J. Yarrow also notes the discrepancy between past and present: "[T] he wretched, pitiful state of the characters in the play is in sharp contrast with the greatness of their parents" (39). Past greatness and present decline are contrasted in the repeated use of the epithet "the son of...." Even though Orestes calls Pyrrhus "Achilles' son, the conqueror of Troy," (I.i.145), the Pyrrhus who rejects Hermione in favor of the captive Andromache is not of the same stature as his father. Phoenix, mentor first to Achilles, then to Pyrrhus, reminds Pyrrhus,

You're not a slavish passion's plaything, but

Pyrrhus, Achilles' rival and his son. (II.v.629-630)

But that reminder stands in direct contrast with the assessment by Cephisa, Andromache's confidante, that Pyrrhus has forgotten his heritage:

Who has forgot he is Achilles' son,

Belies his exploits, makes them meaningless?

(III.viii.990-991)

The contrast is further underscored by Cephisa's use of the French imperfect tense, (“...Achille était son père" - Achilles was his father), a usage which serves as a reminder both of the absent presence of Achilles and the past greatness of the ancestors of Pyrrhus.

Orestes is likewise identified through his father's name. He is the "son of Agamemnon" (I.ii.178) - the Agamemnon who conquered Troy, not the Agamemnon whom the audience will see on the shores of Aulis, ready to sacrifice his daughter in order to set sail for Troy. Wretched, rejected Hermione gains a bit of heroic stature as "Helen's daughter," even when the epithet is spoken in the bitter tones of Andromache, who orders Pyrrhus, "Return, return to Helen's daughter. Go" (I.iv.342).

Hector and Astyanax also belong to the glorious past evoked by naming the heroes of the Trojan War. For Andromache, they represent the reality of the past, a glorious past vanished with the 
ashes of Troy. But for Racine and his audience, Astyanax especially represents the possibility of glory and greatness recaptured. ${ }^{3}$ Andromache's confidante Cephisa triumphantly points out that Astyanax is the embodiment of the future:

\author{
What a joy to rear a child who's growing up \\ No longer for his master as a slave, \\ But as the heir of a long line of kings! \\ (IV.i.1069-1071)
}

Andromache's resolution to die by her own hand immediately after her marriage to Pyrrhus assures a future for her son. By her own death, Andromache proposes to open the way for a new order, represented by Astyanax. Of the four protagonists, only Andromache survives. Pyrrhus and Hermione die, and Orestes goes mad. Not only does Andromache live, but she goes forward from the present of this play into the future as the regent of a new order which Astyanax will ultimately rule. Racine details the result, an order reaching even to the playwright's own era, in his second preface:

For, quite apart from Ronsard, who chose this very Astyanax as the
hero of his Franciade, everyone knows that our kings of olden times are
supposed descended from this son of Hector's, and that our ancient
chronicles save this young prince's life after his country is laid waste,
so as to make of him the founder of our monarchy. (44)

Like Andromache, Iphigenia, first performed in 1674, is peopled by ancestors and heroes who are part of the "human framework" (Prophete 83). Iphigenia is the daughter of Agamemnon, who is eager to set sail for Troy in order to begin the war. But the gods will not send winds favorable to the expedition unless Agamemnon agrees to sacrifice "a daughter with Helen's blood" - a phrase interpreted by all to mean his daughter Iphigenia. After much vacillation and some deception, Agamemnon prepares to complete the sacrifice. But at the last minute, Iphigenia is saved by the revelation that Eriphile - daughter of Helen of Troy and Theseus in a marriage heretofore secret - is also called Iphigenia. It is she who is destined to die. 


\section{Names 42.1 (March 1994)}

In Andromache, the presence of absent ancestors serves to focus the attention of both protagonists and spectators on the past. In direct contrast, the presence of absent family members in Iphigenia focuses the attention of protagonists and spectators on the future. Arcas, the king's companion, reminds Agamemnon of his heritage ("On every side spring from the blood of Jove" [I.i.19]), ${ }^{4}$ thus recalling a majesty which must be sustained, a majesty upheld by naming the great names of the Trojan War: Helen, Priam, Paris, Menelaus (Pfohl 60).

Of all those names which conjure up images of future victory and glory, Menelaus, brother of Agamemnon and King of Troy, is the most conspicuously absent from the scene; he is reduced to a role described by Russell Pfohl as "...a mute passivity in the events which have led up to the assembly at Aulis" (60). Clytemnestra, Agamemnon's queen and Iphigenia's mother, reproaches Agamemnon for assuming what she clearly sees as Menelaus' burden:

Let Menelaus redeem at such a price

His faithless and all too adored wife.

(IV.iv.1271-1272)

Likewise, Achilles protests that his loyalty is to Iphigenia, his betrothed, not to Menelaus:

To her my faith I pledged, to her alone.

Happy to wed, to her I promised all,

Ships, soldiers, arms - and nought to Menelaus.

(IV.vi.1394-1396)

The effect of the absent presence of Menelaus is to make Agamemnon more susceptible to charges of past and present ambition (Pfohl 61), like the one levelled by Clytemnestra: "Who knows not of the pride of Atreus' line?" (III.vii.1065).

Clytemnestra's anger at the king's stance merges with repeated reminders of Agamemnon's ancestry to foreshadow impending doom. That doom resounds in the epithet "son of Atreus," used by both Arcas and Clytemnestra. Arcas recalls the king's heritage in order to remind him of his status: "...father, husband, king, great 
Atreus' son," (I.i.17). Clytemnestra, on the other hand, adopts a bitter, accusing tone:

Yes, you do not belie your hateful race,

You are of Atreus', of Thyestes' blood.

(IV.iv.1349-1250)

Later she calls him "The heir and the true son of Atreus..." IV.iv.1690).

Since the very name of Atreus carried such powerful associations, a brief review of the history of the house of Atreus is in order. Atreus, it may be remembered, was the son of Pelops, whose father was Tantalus and whose grandfather was mighty Zeus. Tantalus was honored above all men by the gods when they agreed to dine with him in his palace. In return for their favor, Tantalus had his only son killed, boiled, and served to his divine guests. Pelops, restored to life by the gods, was, by most accounts, the only one of the descendants of Tantalus not marked by disaster. Pelops and his wife had two sons, Atreus and Thyestes. Upon discovering that Thyestes had seduced his wife, Atreus had Thyestes' two children killed and served to their father. Although Atreus' crime was not avenged in Thyestes' lifetime, his children and his children's children suffered for it. Atreus in his turn had two children, Agamemnon and Menelaus, who married sisters, Clytemnestra and Helen. Menelaus, as noted here, met with misfortune in the temporary loss of his wife, but she was returned to him and they lived happily after the fall of Troy. Agamemnon was less fortunate. During the fighting at Troy, Clytemnestra took as her lover Aegisthus, son of Thyestes. The two of them carried out their plot to kill Agamemnon upon his return from the war. Orestes, son of Agamemnon and Clytemnestra, then murdered his mother to avenge his father's death (Hamilton 237241). Thus the phrase "son of Atreus" not only merges past and present, but hints at disasters to come.

Like Astyanax, Agamemnon, son of Atreus, presents a contrast between past greatness and present decline. While Astyanax serves to foretell the glory of future kings of France, Agamemnon stands as a warning to the king who was present in Racine's audience. Racine 


\section{Names 42.1 (March 1994)}

offers the figure of Agamemnon, son of Atreus, as an example of the dangers of tyranny, a model to be avoided, not emulated..$^{5}$

In the previously mentioned essay on absence and memory, Pitts writes, "Only memory allows the return of the past to human perception, in effect making what was absent, present again" (790). The naming of the absent ancestors of the protagonists thus serves the dramatic function of making what was absent, present. These absences made present by naming create an immediate "bond of long-standing familiarity" between Racine's characters and his audience (Recktenwald 31). The play on the stage was thus unified with its literary antecedents, and the spectators were free to concentrate on the particular conflict before them. Furthermore, those absences-made-present serve to throw the protagonists into stark relief (Defrenne 194) as their actions unfold against the backdrop of personages permanently relegated to the wings. Poetically, those absent presences color the memories of the protagonists (Defrenne 194) - memories which often determine the course of present actions. Finally, those absences-made-present allow the playwright to extend the boundaries sharply defined by the classical theater's rules of unity of time and place: the frantic mother's anguished cries (I.i.147) "...so dreaded by Agamemnon, will also carry the imagination of the audience elsewhere - to the altar, and beyond" (Pfohl 67) - even to the Paris of Racine and his king, Louis XIV.

\section{Greensboro College}

\section{NOTES}

1. This is a revised version of a paper presented at Symposium VI of the Blue Ridge Onomastic Society, held at Greensboro College, 6 April 1991.

2. Jean Racine, Andromache, trans. John Cairncross. (London: Penguin Books, 1967), p. 90. All quotations from the play are from this edition and will be cited in the text by act, scene, and line number.

3. It is important to note that Racine departs from his classical sources in his handling of the character of Astyanax. In Euripides' Andromache, the title character is alone at the court of Pyrrhus, opening the play with this lament: 
But now the unhappiest woman that has ever lived, I have stood by to see my Hector lying dead Beneath Achilles' hand; the boy Astyanax I bore my husband thrown down from the straight tall towers Upon that day when Greeks captured the plain of Troy.

(Euripides, Andromache, in Lind, 293-294; lines 6-10)

According to Racine, only his mother's cleverness had saved Astyanax from the destruction of Troy:

They tell me that, to save the boy from death, Andromache deceived Ulysses' guile.

In fact, another child, snatched from her arms, Was substituted for her son and slain.

(l.i.73-76)

Unlike the Astyanax of Euripides, Racine's Astyanax is alive and well, albeit off-stage and made visible only by the words of the protagonists. Indeed, all her appearances on stage find Andromache either on her way to visit her son or returning from a visit to him.

4. Jean Racine, Iphigenia, trans. John Cairncross. (London: Penguin Books, 1970), p. 55. All quotations from the play are from this edition and will be cited in the text by act, scene, and line number.

5. In The Fabrication of Louis XIV, Peter Burke discusses panegyric, the rhetoric of praise and blame, in seventeenth-century France. While panegyric was often pure praise, it might also be a tactful form of advice, describing a prince not as he was, but as it was hoped he might be (36-37). *

\section{WORKS CITED}

Burke, Peter. The Fabrication of Louis XIV. New Haven: Yale UP, 1992.

Defrenne, Madeleine. "Absence et présence chez Racine." Revue de l'université de Bruxelles 40 (déc. 1961-avril 1962): 192-203.

Euripides. Andromache. Ten Greek Plays in Contemporary Translations. Ed. and trans. L.R. Lind. Boston: Houghton Mifflin Riverside Editions, 1957. 


\section{Names 42.1 (March 1994)}

Hamilton, Edith. Mythology. Mentor Books. New York: New American Library, 1942.

Lapp, John C. Aspects of Racinian Tragedy. Toronto: U Toronto P, 1955.

Pfohl, Russell. Racine's Iphigenie. Literary Rehearsal and Tragic Recognition. Genève: Droz, 1974.

Pitts, Brent A. "Absence, Memory, and the Ritual of Love in Thomas' Roman de Tristan." French Review 63,5 (April 1990): 790-799.

Prophète, Jean. Les Para-personnages dans les Tragédies de Racine. Paris: A-G Nizet, 1981.

Racine, Jean. Andromache. trans. John Cairncross. London: Penguin Books, 1967.

. Iphigenia. trans. John Cairncross. London: Penguin Books, 1970.

Recktenwald, Brother Dionysius, C. F. X. "The Meaning of Racine's Protagonists According to Modern Criticism." Dissertation, Catholic University of America, 1965. 